\title{
Aktivitas Antioksidan Kedelai Edamame Hasil Fermentasi Kultur Campuran oleh Rhizopus oligosporus dan Bacillus subtilis
}

\author{
(Activity of Antoxidants Edamame Soybeans Fermented Result of Mixed Culture by Rhizopus \\ oligosporus and Bacillus subtilis)
}

\author{
Tutus Ervian Ningsih, Siswanto, Rudju Winarsa \\ Jurusan Biologi, Fakultas Matematika dan Ilmu Pengetahuan Alam, Universitas Jember (UNEJ) \\ Jln. Kalimantan 37, Jember 68121 \\ E-mail: siswanto.fmipa@unej.ac.id
}

\begin{abstract}
Abstrak
Kedelai edamame mengandung senyawa isoflavon yang berfungsi sebagai antioksidan. Senyawa tersebut berupa senyawa yang berikatan dengan gula melalui ikatan glikosida. Biokonversi senyawa isoflavon glikosida menjadi isoflavon aglikon yang sangat berpotensi tinggi sebagai antioksidan terjadi selama proses fermentasi oleh aktivitas enzim $\beta$-glukosidase. Dilaporkan enzim $\beta$-glukosidase dihasilkan oleh Rhizopus spp. Selain itu, selama proses fermentasi Bacillus subtilis menghasilkan enzim nattokinase yang juga dapat meningkatkan aktivitas antioksidan. Pada penelitian ini proses fermentasi dilakukan menggunakan inokulum Rhizopus oligosporus, B. subtilis serta campuran keduanya dengan lama fermentasi 24 jam, 48 jam dan 72 jam. Kemudian aktivitas antioksidan diuji menggunakan larutan DPPH (1,1-difenil-2-pikrilhidrazil). Proses fermentasi pada pembuatan tempe edamame dengan inokulum R. oliosporus dan B. subtilis dapat meningkatkan aktivitas antioksidan eksogenous. Aktivitas antioksidan eksogenous tertinggi oleh R. oligosporus sebesar $97 \%$ pada fermentasi 72 jam.
\end{abstract}

Kata Kunci: Kedelai edamame, Isoflavon aglikon, DPPH

\begin{abstract}
Edamame soybeans contains isoflavone compounds that act as antioxidants. Thus compounds are binds to sugars via glycoside bonds. Bioconversion of compounds isoflavone glycosides into isoflavone aglycone very high potential as antioxidants occur during fermentation by the activity of the enzyme $\beta$-glucosidase. It has been reported that $\beta$-glucosidase enzyme are produced by Rhizopus spp. In addition, during the fermentation process of Bacillus subtilis produces an enzyme nattokinase also can increase antioxidant activity. In this study the fermentation process using inoculum Rhizopus oligosporus, B. subtilis as well as a mixture of both with a long fermentation 24 hours, 48 hours and 72 hours. Then the antioxidant activity was tested using a solution of DPPH (1,1-diphenyl-2-picrylhydrazyl). The fermentation process in the manufacture of tempeh inoculum edamame with $R$. olig osporus and B. subtilis can improve exogenous antioxidant activity. The highest exogenous antioxidant activity by R. oligosporus of $97 \%$ in 72 hours fermentation.
\end{abstract}

Keywords: Edamame soybeans, aglycon isoflavone, DPPH

\section{PENDAHULUAN}

Radikal bebas merupakan molekul atau senyawa yang memiliki elektron yang tidak berpasangan, sehingga molekul tersebut menjadi tidak stabil dan bersifat sangat reaktif. Radikal bebas dapat mengakibatkan terjadinya gangguan fungsi sel, kerusakan struktur sel, serta mutasi $[1,2]$. Untuk mencegah atau mengurangi dampak akibat serangan radikal bebas diperlukan antioksidan. Di dalam tubuh terdapat antioksidan endogenous namun jika Radikal bebas mengalami overproduksi dan tidak bisa dikendalikan oleh antioksidan endogenous maka diperlukan antioksidan eksogenous [1,3]. Salah satunya adalah isoflavon yang terdapat dalam kedelai edamame. Isoflavon merupakan senyawa metabolit sekunder yang disintesis oleh tanaman dan senyawa tersebut tidak disintesis oleh mikroorganisme. Dari beberapa jenis tanaman, kandungan isoflavon yang lebih tinggi terdapat pada tanaman Leguminosae, khususnya pada tanaman kedelai [4]. Senyawa tersebut berupa senyawa yang berikatan dengan senyawa gula melalui ikatan glikosida. Jenis isoflavon yang terdapat dalam kedelai adalah genistin, daidzin, dan glisitin [5]. Rerata total isoflavon edamame per 80 gram setelah diolah adalah $49 \mathrm{mg}$, sedangkan kedelai biasa adalah $24 \mathrm{mg}$. Sehingga kandungan isoflavon kedelai edamame lebih besar dibandingkan kedelai biasa [6]. Kedelai edamame dapat diolah dengan cara fermentasi maupun nonfermentasi. Selama proses fermentasi senyawa-senyawa isoflavon yang terikat akan terbebas membentuk isoflavon bebas (aglikon) yang sangat berpotensi tinggi sebagai antioksidan [7]. Biotransformasi isoflavon glikosida menjadi isoflavon aglikon merupakan aktivitas enzim $\beta$ glukosidase. Dilaporkan juga, enzim $\beta$-glukosidase dihasilkan oleh Rhizopus spp. [5]. Kemudian isoflavon aglikon akan bertransformasi lebih kanjut menjadi faktor-II [7]. Faktor-II hanya terdapat pada kedelai yang terfermentasi dan mempunyai sifat antioksidan paling kuat dibandingkan dengan isoflavon lain dalam kedelai non fermentasi [8]. Selain itu, selama proses fermentasi bakteri 
B. subtilis menghasilkan enzim nattokinase yang juga dapat meningkatkan aktivitas antioksidan [9].

Berdasarkan hal tersebut, penelitian ini bertujuan untuk mengetahui aktivitas antioksidan kedelai edamame hasil fermentasi kultur campuran oleh $R$. oligosporus dan $B$. subtilis serta campuran keduanya dengan lama fermentasi 24 jam, 48 jam dan 72 jam.

\section{METODE PENELITIAN}

\section{Penentuan Kepadatan Spora}

Kurva pertumbuhan $R$. olygosporus dibuat dengan cara mengkulturkan spora $R$. olygosporus pada media PDA miring, kemudian diinkubasi pada inkubator pada suhu $30^{\circ} \mathrm{C}$. Setelah itu kultur PDA miring diamati kepadatan sporanya setiap hari berturut-turut selama 7 hari. Pengamatan dilakukan dengan menambahkan $9 \mathrm{ml}$ akuades steril pada tabung kultur. Spora dikerik menggunakan jarum inokulum hingga merata. Suspensi spora yang didapat dipindahkan secara aseptis pada tabung steril dan dihomogenkan. Sebanyak $1 \mathrm{ml}$ suspensi spora diteteskan pada bidang hitung haemocytometer dan dihitung dengan menggunakan mikroskop. Spora yang dihitung adalah spora yang ada pada kotak sedang haemocytometer. Penghitungan dilakukan sebanyak lima kali ulangan. Selanjutnya, jumlah spora/ml sampel ditentukan dengan persamaan berikut:

$$
S=\frac{n}{L x t x d} \times 1000
$$

Keterangan: $\mathrm{S}=$ Jumlah spora/ml; $\mathrm{n}=$ Jumlah spora pada bidang yang dihitung; $\mathrm{L}=$ Luas bidang; $\mathrm{t}=$ kedalaman; $\mathrm{d}=$ Faktor pengenceran

\section{Pembuatan starter R. oligosporus}

Pembuatan inokulum diawali dengan pengukuran pertumbuhan $R$. oligosporus pada media edamame padat dan diinkubasi pada suhu $30^{\circ} \mathrm{C}$ sampai didapatkan kepadatan sel $10^{8} \mathrm{sel} / \mathrm{ml}$.

\section{Pembuatan kurva pertumbuhan B. subtilis}

Pembuatan kurva pertumbuhan $B$. subtilis dengan cara mengkulturkan biakan B. subtilis pada media NB cair $50 \mathrm{ml}$ di dalam erlenmeyer dan diinkubasi shaker dengan kecepatan $150 \mathrm{rpm}$ pada suhu $30^{\circ} \mathrm{C}$ selama 48 jam. Sebanyak $1 \mathrm{ml}$ diambil dan dimasukkan ke dalam $9 \mathrm{ml}$ garam fisiologis sebagai pengenceran $10^{-1}$. Setelah itu diambil $100 \mu \mathrm{l}$ dari pengenceran $10^{-1}$ dan dimasukkan ke dalam microtube yang berisi $900 \mu \mathrm{l}$ garam fisiologis sebagai pengenceran $10^{-2}$. Hal tersebut dilakukan sampai pengenceran $10^{-8}$ dengan interval $4 \mathrm{jam}$. Kemudian sebanyak $5 \mu \mathrm{l}$ diambil dari tiap-tiap pengenceran lalu ditumbuhkan secara drop plate ke media NA dan diinkubasi pada suhu $30^{\circ} \mathrm{C}$ selama 24 jam. Selanjutnya dihitung jumlah koloni yang tumbuh menggunakan metode TPC (total plate count) dengan persamaan:

Jumlah sel $/ \mathrm{ml}(\mathrm{CFU} / \mathrm{ml})=$ Jumlah koloni percawan $\mathrm{x} \underline{1000} \mu \mathrm{l} \times$

$$
1
$$

faktor pengenceran

\section{Pembuatan starter B. subtilis}

Pembuatan starter $B$. subtilis dngan cara mengkulturkan pada $50 \mathrm{ml}$ media edamame cair dan diinkubasi pada suhu $37^{0} \mathrm{C}$ selama 24 jam.

\section{Fermentasi dengan inokulum $R$. oligosporus}

Edamame sebanyak $50 \mathrm{~g}$ direndam dalam air dan dibiarkan selama 9 jam pada suhu $45^{\circ}$ C) [10]. Kedelai dikuliti, dan dikukus selama 1 jam kemudian kotiledon kedelai $(50 \mathrm{~g})$ diletakkan dalam cawan petri dan disterilisasi dalam autoklaf $\left(121^{\circ} \mathrm{C}, 2 \mathrm{~atm}, 30\right.$ menit). Setelah dingin, kotiledon tersebut diinokulasi dengan $R$. oligosporus dan diinkubasikan pada suhu $30^{\circ} \mathrm{C}$ selama 72 jam sampai menjadi tempe. Pengamatan aktivitas antioksidan dilakuan setiap hari selama 3 hari.

\section{Fermentasi dengan inokulum $B$. subtilis}

Edamame sebanyak $50 \mathrm{~g}$ direndam dalam air dan dibiarkan selama 9 jam pada suhu $45^{\circ}$ C) [10]. Kedelai dikuliti, dan dikukus selama 1 jam kemudian kotiledon kedelai (50 g) diletakkan dalam cawan petri dan disterilisasi dalam autoklaf $\left(121^{\circ} \mathrm{C}, 2 \mathrm{~atm}, 30\right.$ menit). Setelah dingin, kotiledon tersebut diinokulasi dengan $B$. subtilis dan diinkubasikan pada suhu $37^{\circ} \mathrm{C}$ selama 72 jam. Pengamatan aktivitas antioksidan dilakuan setiap hari selama 3 hari [11].

Pembuatan Tempe dengan inokulum $R$. oligosporus dan B. subtilis

Edamame sebanyak $50 \mathrm{~g}$ direndam dalam air dan dibiarkan selama 9 jam pada suhu $45^{\circ}$ C) [10]. Kedelai dikuliti, dan dikukus selama 1 jam kemudian kotiledon kedelai $(50 \mathrm{~g})$ diletakkan dalam cawan petri dan disterilisasi dalam autoklaf $\left(121^{\circ} \mathrm{C}, 2 \mathrm{~atm}, 30\right.$ menit). Setelah dingin, kotiledon tersebut diinokulasi dengan $R$. oligosporus kemudian diinokulasi dengan B. subtilis [12]. Fementasi dilakukan pada suhu $37^{\circ} \mathrm{C}$ selama 3 hari [11]. Pengamatan aktivitas antioksidan diakukan setiap hari selama 3 hari.

\section{Ekstraksi sampel}

Ekstraksi dilakukan menurut metode Siregar \& Pawiroharsono yang dimodifikasi. Tempe 50 gr dipotong dengan ukuran 1x1 cm dan dikeringkan dalam oven [13]. Sampel tersebut diblender, kemudian disaring. Menurut metode Weng and Chen yang telah dimodifikasi sebanyak 2 gram sampel direndam dalam $20 \mathrm{ml}$ ethanol $80 \%$ kemudian di waterbath pada suhu $60^{\circ} \mathrm{C}$ selama 1 jam [11]. Ekstrak kemudian disentrifugasi selama 10 menit dengan kecepatan $5000 \mathrm{rpm}$ sehingga akan terpisah antara endapan dan supernatan. Supernatan yang didapat kemudian dikumpulkan dan disimpan untuk uji selanjutnya.

Pembuatan larutan DPPH(1,1-difenil-2-pikrilhidrazil)

Pembuatan larutan DPPH 0,06 mM dengan menimbang Kristal DPPH sebanyak 2,4 mg dan dilarutkan dalam etanol $100 \mathrm{ml}$ [4].

Uji Penangkapan Radikal Bebas dengan Metode DPPH

DPPH merupakan salah satu metode yang digunakan untuk mengukur aktivitas antioksidan dalam makanan atau bahan makanan. Metode DPPH dapat digunakan untuk sampel cair ataupun padat dan tidak spesifik untuk senyawa antioksidan tertentu tetapi untuk keseluruhan senyawa antioksidan yang ada di dalam sampel. DPPH menghasilkan radikal bebas aktif bila dilarutkan dalam alkohol. Radikal bebas tersebut stabil dengan absorpsi maksimum pada panjang gelombang $517 \mathrm{~nm}$ dan dapat direduksi oleh senyawa antioksidan. Dalam metode tersebut ekstraksi sampel hasil fermentasi sebanyak $1 \mathrm{ml}$ ditambahkan $2 \mathrm{ml}$ larutan DPPH 0,06 mM kemudian diinkubasi dalam gelap selama 30 menit dan diukur absorbansinya pada panjang 
gelombang $517 \mathrm{~nm}$ [14]. Larutan DPPH digunakan sebagai kontrol. Analisis dilakukan sebanyak 3 kali pada masingmasing sampel. Persentase aktivitas scavenging DPPH dapat dihitung dengan rumus;

$$
A A=\left(1-\frac{A b s_{\text {sampel }}}{A b s_{\text {kontrol }}}\right) \times 100 \%
$$

\section{Analisis Data}

Data yang diperoleh dianalisis secara deskriptif dan disajikan dalam bentuk tabel, grafik dan foto. Analisis data pada aktivitas antioksidan dari masing-masing sampel dilakukan melalui uji penangkapan radikal secara semikuantitatif dengan metode DPPH.

\section{HASIL PENELITIAN}

\section{Pola Pertumbuhan B. subtilis}

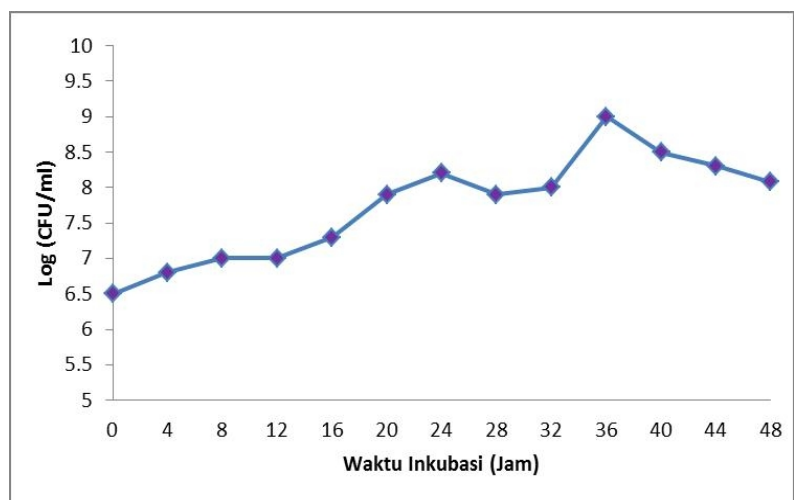

Gambar 1. Kurva pertumbuhan B. subtilis dalam media edamame

Berdasarkan Gambar 1. diketahui bahwa B. subtilis mencapai fase eksponensial atau fase logaritmik pada jam ke-24. Fase tersebut digunakan sebagai starter untuk inokulum. Pada periode tersebut sel akan mampu beradaptasi dengan cepat terhadap media edamame.

\section{Kepadatan spora $R$. oligosporus}

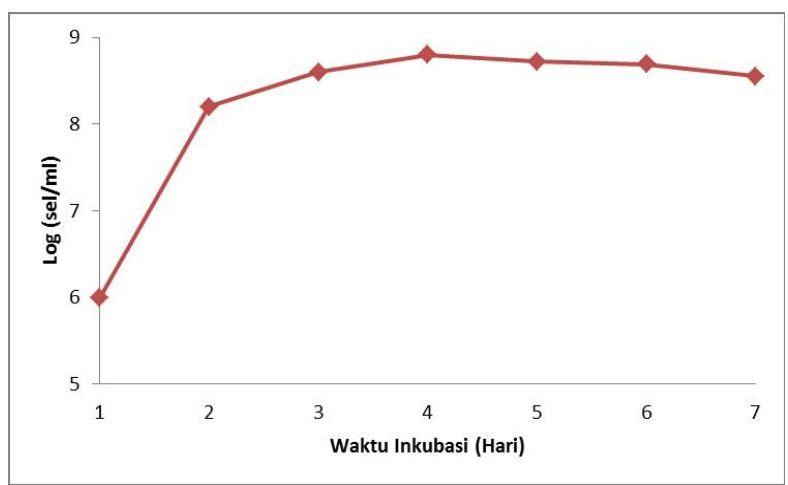

Gambar 2. Kurva kepadatan spora R. oligosporus dalam media edamame

Berdasarkan Gambar 2. dapat diketahui bahwa kepadatan spora mencapai puncak pada waktu inkubasi hari ke 4 dengan jumlah spora sebesar 5,9x $10^{8}$ ( $\left.\mathrm{sel} / \mathrm{ml}\right)$. Jumlah akhir spora/gram substrat tersebut telah memenuhi syarat yang ideal sebagai sumber inolukum yaitu sebesar $10^{6}-$ $10^{8}$. Berdasarkan hasil penelitian dari Mojsov dikatakan bahwa jumlah kepadatan spora yang kurang dari $10^{6}$ spora/gram substrat atau lebih dari $10^{8} \mathrm{spora} /$ gram substrat dapat mempengaruhi aktivitas enzim yang relatif tinggi [15].

Aktivitas antioksidan tempe edamame dengan $R$. oligosporus

Berdasarkan Gambar 3. hasil uji penangkapan radikal bebas dengan metode DPPH menunjukkan aktivitas penangkapan radikal bebas oleh kontrol yang berupa kedelai edamame tanpa isolat yaitu nilai relatifnya sebesar $23 \%$. Aktivitas penangkapan radikal pada sampel edamame hasil fermentasi oleh $R$. oligosporus menunjukkan hasil sebesar $95 \%$ pada fermentasi 24 jam, hasil tersebut mengalami peningkatan menjadi $97 \%$ pada fermentasi 48 jam dan pada fermentasi 72 jam aktivitas penangkapan radikal DPPH semakin meningkat menjadi $100 \%$.

Aktivitas antioksidan menunjukkan peningkatan yang berbanding lurus dengan lama waktu fermentasi ketika difermentasikan menggunakan kultur $R$. oligosporus. Haltersebut berkaitan dengan kepadatan spora dari $R$. oligosporus (Gambar 2.), menunjukkan jumlah spora $R$. oligosporus mengalami peningkatan hingga waktu inkubasi hari ke 4. Peningkatan jumlah spora memiliki pengaruh terhadap peningkatan biomassa selnya sehingga hal tersebut berpengaruh pada aktivitas enzim yang diproduksinya [15] Oleh karena itu semakin meningkat jumlah sel pada $R$. oligosporus maka aktivitas enzim $\beta$-glukosidase yang diproduksi akan meningkat pula. Enzim $\beta$-glukosidase tersebut yang mengkatalis reaksi hidrolisis isoflavon glikosida menjadi aglikon [5]. Fermentasi kapang membutuhkan waktu dua sampai lima hari. Fermentasi kapang selama tiga hari akan menghasilkan enzim yang paling optimum [16]. Sehingga wajar ada kenaikan aktivitas antioksidan sejalan dengan lama fermentasi.

Kenaikan aktivitas antioksidan dapat dilihat berdasarkan perubahan warna pada uji DPPH dari warna ungu menjadi kekuningan. Perubahan warna ungu menjadi kekuningan terjadi karena elektron bebas dari radikal bebas DPPH menjadi berpasangan dengan atom hidrogen yang dilepaskan oleh antioksidan sampel membentuk DPPH-H berwarna kuning dan bersifat stabil [17]. Perubahan warna ini sebanding dengan jumlah elektron zat antioksidan yang diambil oleh radikal DPPH. Semakin tinggi aktivitas antioksidan maka warnanya semakin pudar [18].

Aktivitas antioksidan tempe edamame dengan $B$. subtilis

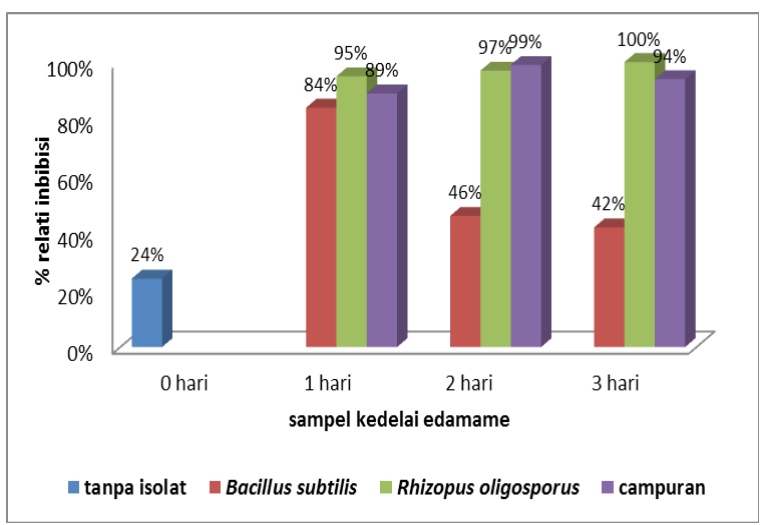

Gambar 3. Aktivitas Penangkapan Radikal DPPH 
Berdasarkan Gambar 3. aktivitas penangkapan radikal DPPH pada sampel edamame yang difermentasi oleh $B$. subtilis selama 24 jam menunjukkan hasil nilai relatif sebesar $84 \%$ dan mengalami penurunan menjadi $46 \%$ untuk fermentasi selama 48 jam serta pada fermentasi selama 72 jam menunjukkan penurunan aktivitas antioksidan menjadi $42 \%$.

Peningkatan aktivitas antioksidan pada produk olahan kedelai fermentasi disebabkan oleh enzim nattokinase yang diproduksi oleh $B$. subtilis selama fermentasi. Mekanisme dari senyawa isoflavon pada natto dalam mengurangi pembentukan senyawa radikal bebas DPPH dapat melalui dua cara yaitu dengan mendonorkan ion hidrogen dari ikatannya dan berperan sebagai penangkap radikal bebas secara langsung [19].

Aktivitas antioksidan kedelai edamame hasil fermentasi oleh $B$. subtilis mengalami peningkatan dan penurunan, hal tersebut dikorelasikan dengan pertumbuhan $B$. subtilis dalam media kedelai edamame. Pertumbuhan B. subtilis dalam media kedelai edamame (Gambar 1.) menunjukkan bahwa aktivitas antioksidan berbanding lurus dengan jumlah B. subtilis dalam kedelai edamame. Aktivitas tersebut meningkat pada fermentasi ke 24 jam yaitu sebesar $84 \%$, kemudian pada fermentasi ke 48 jam mengalami penurunan hingga fermentasi ke 72 jam. Hal tersebut berkaitan dengan pertumbuhan $B$. subtilis dalam media kedelai edamame. Penurunan persentase penangkapan radikal oleh sampel kedelai hasil fermentasi oleh $B$. subtilis dapat dipengaruhi oleh radikal yang dihasilkan selama proses fermentasi. B. subtilis memiliki sistem pertahanan terhadap ROS yang dihasilkan selama proses fermentasi untuk menghindari kondisi tekanan oksidatif [20].

Aktivitas antioksidan tempe edamame dengan $\boldsymbol{R}$. oligosporus dan $B$. subtilis

Pada fermentasi dengan kultur campuran $R$. oligosporus dan B. subtilis berdasarkan Gambar 3. menunjukkan nilai relatif penangkapan radikal DPPH sebesar $89 \%$ pada lama waktu fermentasi 24 jam, aktivitas penangkapan radikal tesebut mengalami peningkatan menjadi 99\% pada fermentasi ke 48 jam dan mengalami penurunan pada fermentasi ke 72 jam sebesar $94 \%$.

Terjadinya peningkatan aktivitas antioksidan pada fermentasi ke 48 jam diduga karena peningkatan aktivitas enzim yang dihasilkan dari $R$. oligosporus sehinga menyebabkan senyawa radikal DPPH yang tertangkap oleh antioksidan lebih besar dari fermentasi ke 24 jam. Selama proses fermentasi kemungkinan besar aktivitas antioksidan berasal dari $R$. oligosporus karena $B$. subtilis kemampuannya semakin menurun dan membebani $R$. oligosporus. Pada fermentasi ke 72 jam mengalami penurunan hal ini diduga karena $B$. subtilis selain menangkap radikal DPPH juga menangkap senyawa radikal lain yaitu hidrogen peroksida yang dihasilkan dari proses metabolisme dalam selnya $[21,22]$. Hidrogen peroksida $\left(\mathrm{H}_{2} \mathrm{O}_{2}\right)$ merupakan radikal yang kurang reaktif akan tetapi pada kondisi tertentu dapat meracuni sel karena meningkatkan kandungan radikal hidroksil [23]. Selain itu selama proses fermentasi $B$. subtilis diduga menghasilkan asam organik seperti asam laktat sehingga menyebabkan pertumbuhan $B$. subtilis pada fermentasi ke 72 jam menjadi semakin tertekan sehingga jumlah sel yang hidup lebih sedikit dibandingkan sel yang mati akibatnya enzim yang dihasilkan menjadi berkurang.

Persentase peningkatan aktivitas antioksidan total pada kedelai edamame hasil fermentasi campuran $R$. oligosporus dan B. subtilis menunjukkan nilai relatif tidak terlalu berbeda jauh. Sehingga dengan adanya pencampuran kultur malah menurunkan optimasi dari $R$. oligosporus dalam meningkatkan aktivitas antioksidan. Dengan kata lain tidak ada pengaruh apabila kultur $R$. oligosporus dan $B$. subtilis digabung dalam froses fermentasi.

\section{KESIMPULAN}

Proses fermentasi pada pembuatan tempe edamame dengan inokulum $R$. oliosporus dan $B$. subtilis dapat meningkatkan aktivitas antioksidan eksogenous. Aktivitas antioksidan eksogenous tertinggi oleh $R$. oligosporus sebesar $97 \%$ pada inkubasi 3 hari. Aktivitas antioksidan eksogenous oleh B. subtilis sebesar $81 \%$ pada inkubasi 24 jam. Dalam inokulum campuran tidak memberikan pengaruh terhadap peningkatan aktivitas antioksidan jika dibandingkan dengan kultur tunggal $R$. oligosporus.

Proses fermentasi dengan menggunakan kultur campuran antara $R$. oliosporus dan $B$. subtilis perlu dilakukan penelitian yang lebih lanjut dengan metode pencampuran yang divariasi dan juga perlu dilakukan penghitungan populasi setelah pencampuran.

\section{DAFTAR PUSTAKA}

[1] Winarsi, H. 2007. Antioksidan Alami Dan Radikal Bebas. Yogyakarta: Kanisius.

[2] Ramasarma, T. 2012. Emergencce of Oxyl Radicals as Selective Oxidants. Indian Journal of Biochemistry and Biophysics, 49: 295-305.

[3] Youngson, R. 2005. Antioksidan: Manfaat Vitamin C Dan E Bagi Kesehatan. Jakarta: Arcan.

[4] Istiani, Y. 2010. Karakterisasi Senyawa Bioaktif Isoflavondan Uji Aktivitas Antioksidan Dari Ekstrak Etanol Tempe Berbahan Baku Koro Pedang (Canavalia Ensiformis).[Tesis]. Surakarta: Program Studi Biosains, Universitas Sebelas Maret.

[5] Purwoko, T., Pawiroharsono, S., dan Gandjar, I. 2001. Biotransformasi Isoflavon oleh Rhizopus oryzae UICC 524.Biosmart, 3(2), 7-12.

[6] Riyanto, C. 2014. Kualitas Mi Basah Dengan Kombinasi Edamame (Glycine Max (L.) Merrill) Dan Bekatul Beras Merah. [Skripsi]. Yogyakarta: Program Studi Biologi, Universitas Atma Jaya Yogyakarta.

[7] Gyorgy, P., Murata, K., and Ikehata, H. 1964. Antioxidants Isolated from Fermented Soybeans (Tempeh). Nature. 203: 870-872.

[8] Afiyata, N., Sarosa, H., dan Sumarawati, T. 2011. Pengaruh Tempe terhadap Kemampuan Fagositosis Makrofag Studi Eksperimental pada Mencit Jantan Strain Balb/c. Sains Medika, 3(1): 54-62.

[9] Putri, Y.E.K., Susilowati dan Lestari, S.R. 2013. Pengaruh Natto Kedelai Hitam (Glycine soja L.) Terhadap Kadar Malondialdehid (Mda) Hepar Mencit yang Diinduksi Diet Tinggi Lemak. [Artikel Penelitian]. Malang: Jurusan Biologi, FMIPA, 
Universitas Negeri Malang.

[10] Purwoko, T. 2004. Kandungan Isoflavon Aglikon pada Tempe Hasil Fermentasi Rhizopus microsporus var. oligosporus: Pengaruh Perendaman. BioSMART, 6(2): 85-87.

[11] Weng, T.M., and Chen, M.T. 2011. Effect of TwoStep Fermentation by Rhizopus oligosporus and Bacillus subtilis on Protein of Fermented Soybean. Food Sci. Technol. Res., 17 (5), 393 - 400.

[12] Chen, L., Madl, R.L., Vadlani, P.V., Wang, L., dan Wang, W. 2013. Value - Added Products from Soybean: Removal of Anti-Nutritional Factors via Bioprocessing. licensee InTech.

[13] Siregar, E. and S. Pawiroharsono. 1997. Inocula formulation and its role for biotransformation of isoflavonoid compounds. Proceeding of International Tempe Symposium.

[14] Garcia, E.J., Oldoni, T.L.C., De Alencar, S.M., Reis, A., Loguercio, A.L., dan Grande, R.H.M. 2012. Antioxidant Activity by DPPH Assay Of Potential Solutions To Be Applied on Bleached Teeth. Braz Dent. J, 23(1): 22-27.

[15] Mojsov, K. 2010. Experimental Investigations of Submerged Fermentation and Synthesis of Pectinolytic Enzymes by Aspergillus niger: Effect of Inoculum Size and Age of Spores. Journal of Technologies and Innovations, 2(2): 40-45.

[16] Frazier, W.C. and Westhoff, D.C. 1978. Food Microbiology. New York: McGraw Hill Book Company.

[17] Prakash, A., Rigelhof, F., \& Miller, E. 2001. Antioxidant Activity. Medallion Laboratories Analitical Progress, 19 (2): 1-4.

[18] Sabuluntika, N. 2013. Kadar p-Karoten, Antosianin, Isoflavon, Dan Aktivitas Antioksidanpada Snack Bar Ubi Jalar Kedelai Hitam Sebagai Alternatif Makanan Selingan Penderita Diabetes Melitus Tipe 2. [Artikel Penelitian]. Semarang: Program Ilmu Gizi, Fakultas Kedokteran, Universitas Diponegoro.

[19] Pokorny, J., Yanishlieva, N., \& Gordon, M. 2001. Antioxidant In Food: Practical Application. New York: Press Cambridge.

[20] Dajanta, K., Janpum, P. and Leksing, W. 2013. Antioxidant Capacities, Total Phenolics and Flavonoids in Black and Yellow Soybeans Fermented by Bacillus subtilis: A Comparative Study of Thai Fermented Soybeans (thua nao). International Food Research Journal. 20 (6): 3125-3132.

[21] Shrestha, A. K., Dahal, N. R., and Ndungutse, V. 2010. Bacillus Fermentation of Soybean: A Review. $J$. Food Sci \& Technol, 6(1-9).

[22] Yang, J.H., Mau, J.L., Ko, P.T., dan Huang, L.C. 2000. Antioxidant Properties of Fermented Soybean Broth. FoodChem. 71: 249-254.

[23] Suryanto, E. dan Wehantouw, F. 2009. Aktivitas Penangkap Radikal Bebas dari Ekstrak Fenolik Daun Sukun (Artocarpus altilis F.). Chem. Prog, 2(1). 